\section{Assessing Vulnerability Along a Dynamic Coastline: The Example of the Sidi Frej Tourist Area in the Kerkennah Archipelago}

Gl_Forum 2016, Vol.1

Page: $141-148$

Full Paper

Corresponding Author: lucileetienne1985@gmail.com

DOI: 10.1553/giscience2016_01_s141

\author{
Lucile Etienne \\ Université Paris Diderot - Sorbonne Paris Cité, France
}

\begin{abstract}
The Kerkennah archipelago is composed of low islands where the lithology is fragile. The coasts are also threatened by the rise in sea level $(+17 \mathrm{~cm}$ between 1946 and 2006) due to the subsidence in the north of the Gabes gulf and the increase of sea water temperatures. Tunisian society has changed in the last 50 years with, inter alia, a rise in the standard of living and the possibility of building houses and villas along the coast. In the Kerkennah archipelago, this has led to recent urbanization along the coastline. In this very fine-scaled example, we aim to assess the vulnerability linked with this socio-ecosystem that combines human and natural factors. We also take into account the spatial (and temporal) dynamic associated with the longshore drift. Our results show that (i) the spatial dynamic is a critical factor that needs consideration, and (ii) the assessment process requires excellent knowledge of the area being studied. Finally, we conclude that in the context of the development of systemic studies, both the territories themselves and the relations between the different areas that compose a territory must be studied as factors of vulnerability.
\end{abstract}

\title{
Keywords:
}

Kerkennah, vulnerability assessment, coastline dynamics

\section{Introduction}

Studies on vulnerability linked to the impacts of climatic change on territories and societies often use the concept of the socio-ecosystem (Cutter \& Finch, 2008). Preston et al. (2011) argue that Expanded Vulnerability (EV) models must consider physical and human factors of vulnerability. Adger (2006) and Meur-Ferec (2009) add that the vulnerability of a territory is linked to (i) its physical conditions and (ii) human characteristics, but also (iii) the relations between parts of the territory and between humans and/or physical components. In practice, most studies on coastal vulnerability at the local level divide the territory concerned and assess the vulnerability of each separate small portion of coast (Pendleton et al., 2003; Abuodha \& Woodroffe, 2010; Luo et al., 2013; Bagdanavičiūtè et al., 2015; Benassai et al., 2015). This partitioning leads to overlooking the spatial continuum and the dynamics of the coast, and especially the impact of longshore drift and of the human infrastructures on the 
vulnerability of the coast. In this study, we argue that vulnerability should be studied from a systemic point of view and that the relations that exist between the area's various components must be taken into account.

We use a systemic approach to assess the vulnerability on the tourist area of the Kerkennah archipelago in Tunisia (Figure 1). The archipelago is composed of small $\left(0.5 \mathrm{~km}^{2}\right.$ to 11,000km²; (Péron, 1993; Taglioni, 2006; Bouchard et al., 2010)), and very small islands (less than $0.5 \mathrm{~km}^{2}$ ) which are known to be highly vulnerable to the recent climate change and social developments (Fehri, 2011; Etienne, 2014). An understanding of the recent history of sociological change, urban expansion and present climate change was a necessity, and the study focuses on the last 60 years, from the mid-twentieth century to the present. The tourist area of Sidi Frej, which is located along the north-west coast of Chergui Island (Figure 1), is $7 \mathrm{~km}$ long and presents an alternation of "natural" and protected stretches of coast, including hotels, roman remains (notably the ancient city of Borj el H'sar), and villas that are inhabited mostly during the summer period.

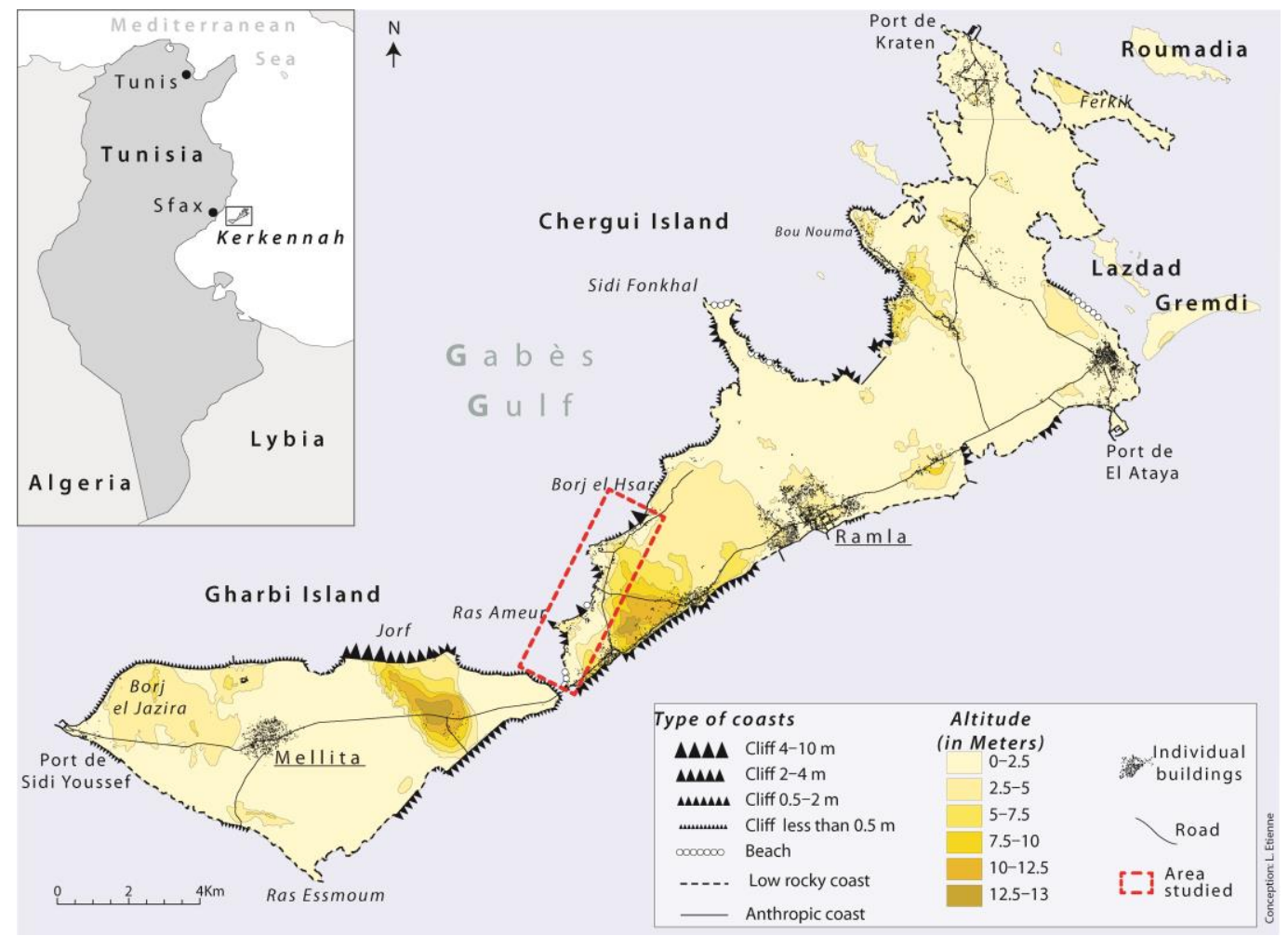

Figure 1: The Kerkennah Archipelago, coast type, altitudes and area studied. Sources: Spot 5 TM image of 2010 (Resolution 2.5m) and topographic map of 1973 (scale 1:25000).

This study aims to assess the vulnerability of a partially-urbanized coastal tourist area by examining anthropogenic and physical factors. The assessment of the vulnerability needs to 
identify these factors but also to understand the spatial relations that exist along the coast. Indeed, longshore drift greatly influences the distribution of the accumulation of sediments / erosion areas, and human infrastructures disrupt the coastal dynamics. The aim is also to take into account the spatial relations between sections of the coast, both in our assessment of the vulnerability and for the purposes of their cartographic representation.

\section{Disruption of the natural dynamics by human infrastructures, and increased vulnerability}

\section{Coastal vulnerability factors in the Kerkennah archipelago}

To assess the coastal vulnerability in the Kerkennah archipelago, we used the Coastal Vulnerability Index developed by Gornitz et al. (1994). We adapted it to correspond to the specific characteristics of the islands' coasts and the available data, and to take into account human variables. The coastline studied was divided in $36200 \mathrm{~m}$-long sections (Figure 2) using the DSASTM (Digital Shoreline Analysis System) module of ArcGis ${ }^{\text {TM }}$. In each section, the vulnerability was assessed using GIS. The results ranged from 3 (lowest vulnerability) to 10 (highest vulnerability), depending on the different variables. The assessment of coastal vulnerability presented here uses 3 physical variables and 2 human variables (Figure 2). The factors used may be theoretical, such as the susceptibility to erosion and submersion, and are therefore not directly visible in the field. To represent these theoretical factors of vulnerability, Gallopín (1997) and Hinkel (2011) use indicators, defined as mathematical functions that transform an observable variable (e.g. a physical phenomenon) into a theoretical variable (e.g. the susceptibility to the physical phenomenon). The susceptibility to submersion, for instance, is a theoretical variable (not directly visible) but, because it depends on the height of cliffs, the height can be used as an observable variable (Figure 2). The same analogy can be made between erosion susceptibility and the lithology (Figure 2). Other variables, such as the presence of stakes along the coast, and the influence of sea defences, are more visible and do not require any additional observable variable to be defined.

\section{Fragile coasts and impact of recent climate change}

The result of the recent evolution of regional factors - climate change and Sea Level Rise (SLR) - is an increase of the vulnerability for the coast of the Kerkennah archipelago. Indeed studies concerning climate change in the area show:

- the lengthening of the summer period and the increase of summer temperatures since the 1950s (Dahech, 2007)

- SLR (Saidani, 2007) caused on the one hand by the rise of sea temperatures, and on the other by the high level of subsidence in the north of the Gabes gulf, which may have an impact on the coastal erosion (Oueslati, 1995)

- the change of wind speed and direction since the 1970s (Dahech \& Beltrando, 2012), which could have an impact on wave height, but also on the direction of waves and therefore on coastal submersion and erosion. 
To assess the theoretical variable of erosion vulnerability at fine scale, we used the observable variable of the lithology. A coast composed of solid materials was considered to be only slightly vulnerable; a coast made of soft material was considered very vulnerable (Figure 2). To assess the vulnerability to submersion at fine scale, we used the height of the coast as an indicator. A very low coast was considered very vulnerable, while a high cliff (more than 2m) was considered to be little vulnerable (Figure 2). In the Sidi Frej area, the natural components of the coast are variable. The minimal "natural" vulnerability was observed in Ras Ameur (Figure 2), where the coast is strong, of a Pleistocene calcareous crust (Oueslati, 1986), and high (approximatively 2m); the maximal vulnerability was observed near the bridge of El Kantara (south of the area), where the coast is low and sandy (Figure 2).

\section{Direct and indirect impact of coastal amenities on the vulnerability assessment}

The presence of physical issues along the coastline is a factor of vulnerability (Figure 2). A distinction is made here between houses or Roman remains, which are considered issues, and institutional or industrial buildings (especially the water desalination plant in Ramla; see Figure 1), which are considered major issues because of their importance for the community. The villas, hotels and remains that were built along the coastline are considered "normal" issues.

In addition to their immediate local influence, coastline developments (Figure 3) have an impact on vulnerability, as they lead to the disruption of the coastal dynamics associated with the longshore drift and the relationships between the different parts of the coastline. The division of a territory into small coastal sections assessed independently, with no analysis of the interplay between them, hides the complexity of the coastline dynamics. A construction built to protect the coastline against sea erosion and submersion will have different effects in time and space. In the short term, it will protect the land located just behind it, but it will also disrupt the coastal dynamics and so have indirect consequences, of high erosion rates (Etienne, 2014), on the adjacent section of coast (Figure 2: see the arrows on the left, showing the direction of the longshore drift). In the longer term, the construction will be affected by the reduction in the quantity of sediments in front of it (Oueslati, 2010) and by its own erosion by the sea. The high rates of erosion measured beside the construction will stay high but could be exacerbated by fragments from the eroded construction itself that favour mechanical erosion. In the archipelago, this situation is frequent along the coastline and can be summarized in a system (Figure 3). 


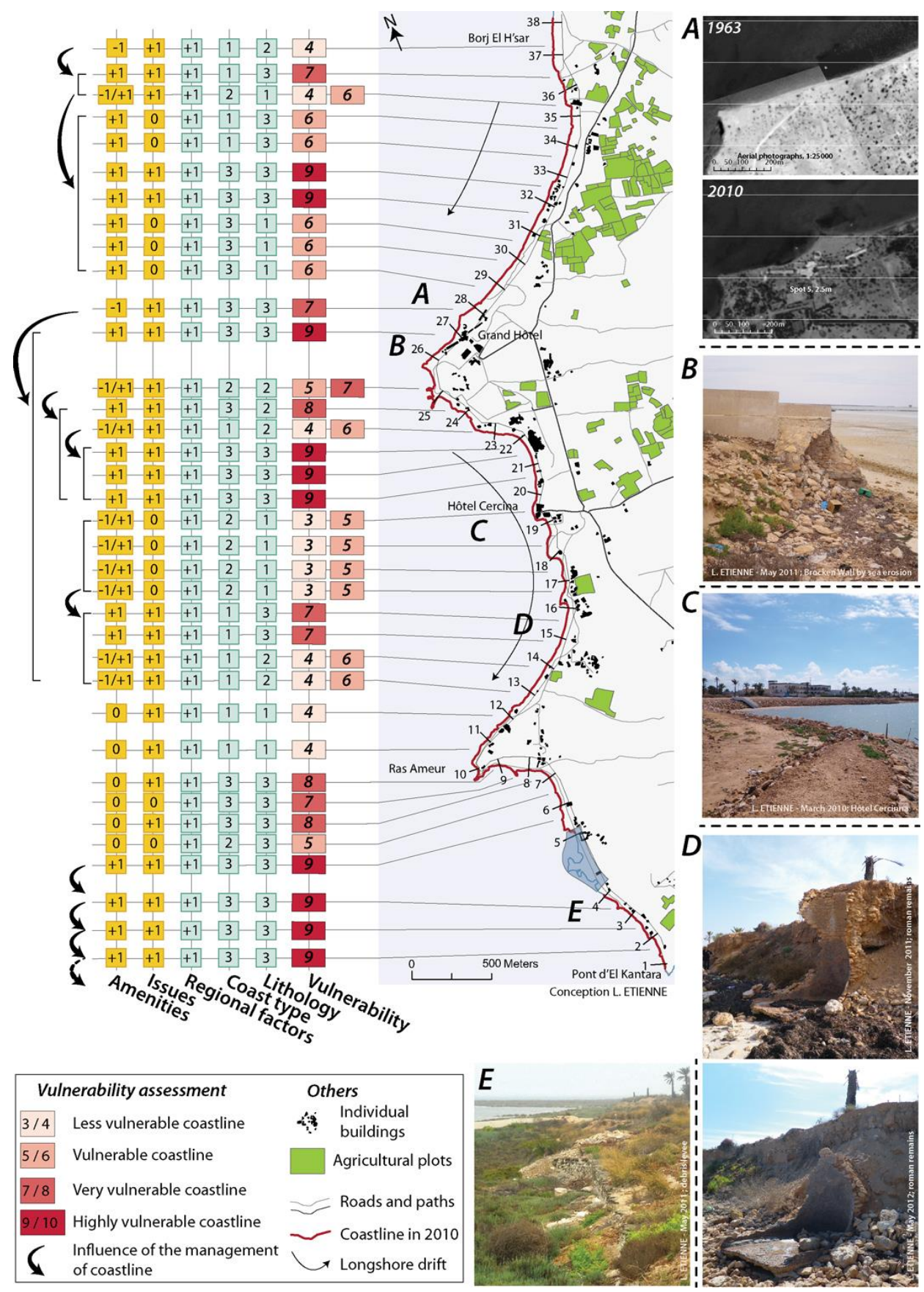

Figure 2: Assessment of coastal vulnerability in the tourist area of Sidi Frej. A: Coastline evolution between 1963 and 2010 in front of the Grand Hôtel due to the creation of an artificial beach; B: Individual sea wall eroded by the sea; C: Dyke in front of the Cercina hostel; D: Roman remains discovered in the cliff, destroyed by erosion within 6 months; E: Terrigenous and worksite debris levees. Each $200 \mathrm{~m}$ coastal section received a rank of 3 (low vulnerability) to 10 (high vulnerability). All photographs are the author's own. 
The defences against erosion and submersion along the tourist coast of Sidi Frej are various. We observed the alternation of "natural" areas and ones where there had been human intervention: hotels and villas that were individually protected by terrigenous or worksite debris levees, or by sea walls (Figure 2: B and E); the Cercina hostel protected by a breakwater and embankments built by the State (Figure 2: C). This heterogeneity leads to the exacerbation of differential erosion, especially in the unprotected and easily erodible areas. The management of this coast began in the 1970s with the installation of the Grand Hôtel in the north and the realization of a sand trap to create an artificial beach (Figure 2: A; Figure 3). The presence of the sand trap led to a deficit in sand for the areas located immediately to the south - which have high vulnerability scores (Figure 2: A and D). These events justified the construction of the first individual sea wall and levee (Figure 2: B), which favoured, in turn, the erosion of the coast located just to their south and triggered the need for the other inhabitants to try to protect themselves. Those sea walls and other relatively old infrastructures are already weakened (and sometimes broken; see Figure 2: B) and need to be consolidated or rebuilt every year. In this situation, we consider the lowest vulnerability in the short term, and a higher long-term vulnerability. The walls, constituted of rocks, or worksite debris levees lose fragments, which are taken by the sea, where they are broken and eroded into smaller materials. These fragments then exacerbate the mechanical erosion (Figure 2: B and E), thereby increasing vulnerability in the direction of the longshore drift. This phenomenon is accentuated by the recent urban extension along the coasts of the archipelago (Kebaili Tarchouna, 2013). Recently, the Cercina hostel has benefited from the renovation of the nearby dyke and the installation of rockfill embankments by the State to counter erosion and favour the development of the beach. The impact on the areas located just beyond these embankments is significant, as shown by the uncovering in 2010 of Roman remains previously buried in the cliffs, their degradation in 2011, followed by their almost complete disappearance in 2012 (Figure 2: D).

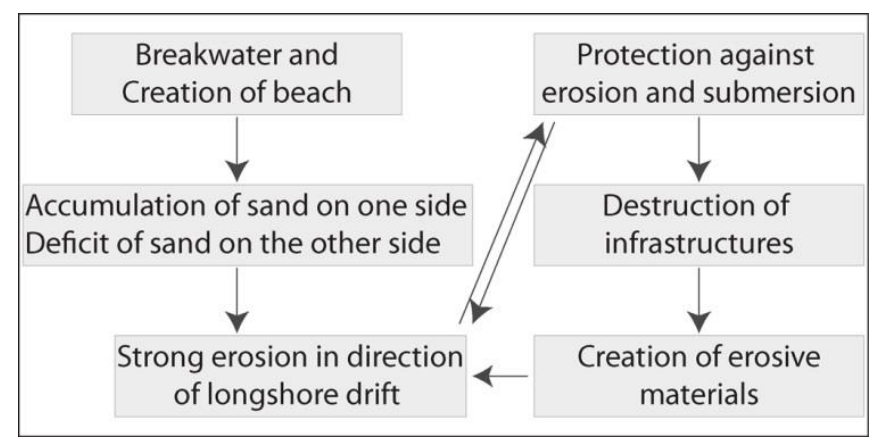

Figure 3: Systemic view of the process of vulnerability accentuation

The positive feedback loop described above and summarized in Figure 3 tends to increase vulnerability both in time and space because of the enduring nature of the disruption of the coastal dynamics and the redistribution and concentration of wave energy in the unmanaged areas. These indirect and antagonistic influences of the infrastructures both inside and outside each section of coast must be taken into account to improve our assessment of vulnerability. 


\section{Conclusion}

The division of a territory is a convenient method that is still frequently used in vulnerability assessment studies. However, the consideration of spatial relations is essential, at least in the example of the Kerkennah archipelago, to understand the vulnerability process. Our aim was to link, on the one hand, the fractioning of the coast, with, on the other, the need to reestablish the spatial relationships between each section of coast in order to complete the vulnerability assessment. We achieved our goal thanks to excellent knowledge of the field, of the physical processes involved, and of the recent history of the coastal urbanization. The mapping itself is based on the classical representation of coastal vulnerability indexes (section by section), to which were added spatial relations linked to the longshore drift and the disturbances caused by man-made infrastructures. Coastal protection measures recently implemented by the State (2014-2015) along the archipelago's coastline are rockfill or walls, which are heavy measures. These heavy amenities will protect, for a time, the areas located just behind, but they favour coastal erosion in the direction of the longshore drift, as observed in Sidi Frej. In order to develop integrated and sustainable policies, spatial dynamics must therefore be given far greater consideration, not only by researchers but also by stakeholders in a territory.

\section{Acknowledgements}

This work was supported by the CMCU - EGIDE - Utique project under Grant $11 \mathrm{G} 0406$. I thank Sfax University colleagues S. Dahech and R. Bouaziz for field support, and my PhD supervisor A. Daoud (Tunisia). This paper is dedicated to G. Beltrando, my $\mathrm{PhD}$ cosupervisor (France).

\section{References}

Abuodha, P. A. O., \& Woodroffe, C. D. (2010). Assessing vulnerability to sea-level rise using a coastal sensitivity index: a case study from southeast Australia. Journal of coastal conservation, 14(3), 189205.

Adger, W. N. (2006). Vulnerability. Global Environmental Change, 16(3), 268-281.

Bagdanavičiūtė, I., Kelpšaitė, L., \& Soomere, T. (2015). Multi-criteria evaluation approach to coastal vulnerability index development in micro-tidal low-lying areas. Ocean \& Coastal Management, 104, 124-135. doi: 10.1016/j.ocecoaman.2014.12.011

Benassai, G., Di Paola, G., \& Aucelli, P. P. C. (2015). Coastal risk assessment of a micro-tidal littoral plain in response to sea level rise. Ocean \& Coastal Management, 104, 22-35. doi: 10.1016/j.ocecoaman.2014.11.015

Bouchard, C., Marrou, L., Plante, S., Payet, R., \& Duchemin, A. (2010). Les petits états et territoires insulaires face aux changements climatiques: vulnérabilité, adaptation et développement. VertigOLa revue électronique en sciences de l'environnement, 10(3), -. Retrieved from http://vertigo.revues.org/10634 doi:10.4000/vertigo.10634

Cutter, S. L., \& Finch, C. (2008). Temporal and spatial changes in social vulnerability to natural hazards. Proceedings of the National Academy of Sciences, 105(7), 2301-2301. 
Dahech, S. (2007). Le vent à Sfax (Tunisie), impacts sur le climat et la pollution atmosphérique. Thèse de l'Université de Paris 7. pp. 351.

Dahech, S., \& Beltrando, G. (2012). Observed temperature evolution in the City of Sfax (Middle Eastern Tunisia) for the period 1950-2007. Climatic Change, 114(3-4), 689-706. doi: 10.1007/s10584-012-0420-x

Etienne, L. (2014). Accentuation récente de la vulnérabilité liée au recul du trait de côte et à l'extension des sebkhas dans l'archipel de Kerkennah (Tunisie). Thèse de doctorat de Géographie et Environnement - Doctorat en Science Géographiques, Université Paris Diderot (Paris 7) Université de Sfax. Retrieved from https://tel.archives-ouvertes.fr/tel-01075029, pp. 326.

Fehri, N. (2011). La palmeraie des îles Kerkennah (Tunisie), un paysage d'oasis maritime en dégradation: déterminisme naturel ou responsabilité anthropique? Physio-Géo. Géographie, physique, et environnement, 5, 167-189.

Gallopín, G. C. (1997). Indicators and their use: information for decision-making. (pp. 13-27): SCOPE-Scientific Committee on Problems of the Environment International Council of Scientific Unions 58

Gornitz, V. M., Daniels, R. C., White, T. W., \& Birdwell, K. R. (1994). The Development of a Coastal Risk Assessment Database: Vulnerability to Sea-Level Rise in theU.S. Southeast. Coastal hazards: perception, susceptibility and mitigation, Special Issue No. 12, 327-338.

Hinkel, J. (2011). "Indicators of vulnerability and adaptive capacity": Towards a clarification of the science-policy interface. Global Environmental Change, 21(1), 198-sa208. doi: 10.1016/j.gloenvcha.2010.08.002

Kebaili Tarchouna, M. (2013). L'archipel de Kerkena: organisation de l'espace et aménagement. Thèse de l'Université de Tunis. Faculté des Sciences Humaines et Sociales de Tunis. Ecole Doctorale : Structures, Systèmes et Modèles. pp. 301.

Luo, S., Wang, H., \& Cai, F. (2013). An integrated risk assessment of coastal erosion based on fuzzy set theory along Fujian coast, southeast China. Ocean \& Coastal Management, 84, 68-76. doi: 10.1016/j.ocecoaman.2013.07.007

Meur-Ferec, C. (2009). Protection contre la mer ou repli stratégique. Quelles stratégies face aux risque d'érosion-Submersion côtière. Festival de Géographie, St Dié des Vosges. Retrieved from doi:http://www.cndp.fr/fig-st-die/2009

Oueslati, A. (1986). Jerba et Kerkna: îles de la côte orientale de la Tunisie. Leur évolution géomorphologique au cours du quaternaire: Université de Tunis.

Oueslati, A. (1995). The evolution of low Tunisian coasts in historical times: From progradation to erosion and salinization. Quaternary International, 29-30, 41-47.

Oueslati, A. (2010). Plages et urbanisation en Tunisie : des avatars de l'expérience du XXè siècle aux incertitudes de l'avenir. Méditerranée, 115, 103 - 116.

Pendleton, E. A., Hammar-Klose, E. S., Thieler, E. R., \& Williams, S. J. (2003). Coastal Vulnerability Assessment of Gulf Islands National Seashore (GUIS) to Sea-Level Rise (pp. 22).

Péron, F. (1993). Des îles et des hommes: l'insularité aujourd'hui: Editions de la Cité.

Preston, B. L., Yuen, E. J., \& Westaway, R. M. (2011). Putting vulnerability to climate change on the map: a review of approaches, benefits, and risks. Sustainability Science, 6(2), 177-202. doi: $10.1007 / \mathrm{s} 11625-011-0129-1$

Saidani, N. (2007). Rapport du centre hydrographique et oceanographique de la marine nationale de la Tunisie (pp. 5).

Taglioni, F. (2006). Les petits espaces insulaires face à la variabilité de leur insalurité. Annales de Géographie, 652, 664-687. 